\title{
References
}

Cann, J. R. 1969. Spilites from the Carlsberg Ridge, Indian Ocean. J. Petrology 10, 1-19.

Chinner, G. A. \& Fox, J. S. 1974. The origin of cordierite-anthophyllite rocks in the Land's End aureole. Geol. Mag. 111, 397-408.

Floyd, P. A. 1965. Metasomatic hornfelses of the Land's End aureole at Tater-du, Cornwall. J. Petrology 6, 223-45.

Floyd, P. A. 1968. Distribution of $\mathrm{Cu}$ in the basic hornfelses of the Land's End aureole, Cornwall and other chemically similar rocks. Geochim. cosmochin. Acta 32, 879-96.

Floyd, P. A. \& Lees, G. J. 1972. Preliminary petrological and geochemical data on the Cudden Point greenstone. Proc.Ussher Soc. 2, 421-3.

Melson, W. G. \& van Andel, J. H. 1966. Metamorphism in the Mid-Atlantic Ridge, $22^{\circ}$ N. latitude. Marine Geol. 4, 165-86.

Melson, W. G., Thompson, G. \& van Andel, T. H. 1968. Volcanism and metamorphism the Mid-Atlantic Ridge, $22^{\circ}$ N. latitude. J. Geophys Res. 73, 5925-41.

Morton, R. D. \& Smith, D. G. W. 1971. Differentiation and metasomatism within a Carboniferous spilite-keratophyre suite in S.W. England. Spec. Paper Mineral. Soc. Japan, 1, 127-33.

Tilley, C. E. 1935. Metasomatism associated with the greenstone-hornfelses of Kenidjack and Botallack, Cornwall. Mineralog. Mag. 24, 181-202.

Vallance, T. G. 1965. On the chemistry of pillow lavas and the origin of spilites. Mineralog. Mag. 34, 471-81.

Vallance, T. G. 1967. Mafic rock alteration and isochemical development of some cordierite-anthophyllite rocks. J. Petrology 8, 84-96.

Vallance, T. G. 1969. Spilites again: some consequences of the degradation of basalts. Proc. Linn. Soc. N.S.W. 94, 8-51.

Wilson, I. R. \& Floyd, P. A. 1974. Distribution of uranium in the Land's End granite and aureole, and various greenstones from Cornwall. Proc. Ussher Soc. (In the press).

P. A. FLOYD

Department of Geology

University of Keele

Staffordshire, ST5 5BG

England

29th October 1974

\section{Slickensides and slickenlines}

SIR - A recent article (Weaver, 1974) prompts me to draw attention to the current confusion concerning the meaning of the term slickenside. The International Tectonic Dictionary (Dennis, 1967, p. 136) gives a definition which indicates that a slickenside is a polished surface (i.e. a planar structure). Unambiguous definitions with the same meaning are given by Billings $(1972$, p. 201$)$, Spencer $(1969$, p. 70$)$ and Stozes \& White $(1935$, p. 191). Such a definition is obviously implied by the use of the word side as part of the term, and is in agreement with the original meaning (cf. Conybeare \& Phillips, 1822 , p. 348 ; Lyell, 1874 , p. 64). Other geological dictionaries concur with this meaning of the term (American Geological Institute, 1957, p. 269; Challinor, 1967; p. 231; Schieferdecker, 1959, pp. 111, 173) as do some published descriptions (e.g. Lindström, 1974). It is generally accepted that two other types of structure are commonly associated with such surfaces, namely linear structures in the form of striations or grooves, and minute step structures at a high angle to the lineations. These features are believed to reflect the displacement direction on the surface.

However, it is common in the more recent literature to find the term slickenside used

Geol. Mag. 112 (3), 1975, pp. 319-322. Printed in Great Britain. 
for the linear feature, as can beseen from some textbook definitions (Hills, 1972, p. 179: Nevin, 1949, p. 130; Read \& Watson, 1962, p. 466; Verhoogen et al. 1970, p. 146) and a number of descriptions of these structures (e.g. Ramsay, 1967, p. 392; Tjia, 1964, p. 683). Weaver (1974, pp. 332-3) uses slickenside for the linear structure, but this is not obvious until one reads the word 'plunge' applied to the attitude. Such unintentional ambiguity is common, and in many descriptions it is not completely clear whether the term is being applied to the linear structure alone or the combination of planar and linear structure (e.g. Badgley, 1965, pp. 12, 15, 181; Gay, 1970; Paterson, 1958, p. 469; Rod, 1966). In other cases inconsistency is evident (see the contrast between definition and usage in Spencer, 1969, pp. 42,70,185). Dennis's (1972, p. 278) more recent definition of slickensides as 'sets of polished striations' illustrates the ambiguities current in the usage of the term.

Such confusing usage for a simple, common term seems quite unnecessary, leads to misunderstanding and poor communication of information, and causes one to waste time on semantic considerations when teaching. It may arise for two reasons. First, even in those sources which clearly define the structure as a plane, considerable emphasis is placed on the almost invariable presence of linear structures as well. Lyell's (1874) admirably clear description illustrates this point very well. Second, one suspects an understandable unwillingness to write 'striations on a slickenside surface', which is the only unambiguous way of describing the linear structure, given the lack of a simple term.

In the interests of clearer description some revision of the terminology for these structures would be helpful. It is obvious that three different types of structure are present, of which the primary one is the shear surface, typically polished. This may or may not carry the other two structures, and therefore all three require distinctive names which emphasize their particular natures. Priority and etymology suggest that slickenside be reserved for the shear surface itself, and accordingly I propose that the following terms and definitions may be appropriate:

Slickenside: 'A polished and commonly, though not invariably, striated shear surface in rocks.'

Slickenline: 'A linear structure, either striation or grooving, resulting from friction on a slickenside.'

Slickenstep (Slickenside step): 'A minute step feature in a slickenside, usually approximately perpendicular to slickenlines.'

It remains to mention that some of the structures described in the literature as slickensides, slickenside striations and slickenside steps are not in fact the result of friction during shear movements. Those structures formed in shear zones of finite width, at an angle to the sides of the zone, by the overlapping of bundles of quartz or calcite growth fibres, bear a superficial resemblance to the structures defined above, although the linear feature is not precisely parallel to the shear plane. However, they do not conform with any of the available definitions of slickensides, since they result from crystal growth and not abrasion. Hills (1972, fig. VII-17, p. 180) appears to depict a good example of this type of growth structure, the dynamic interpretation of which may be analogous with that of slickensides proper, even though the genesis differs. Further consideration of the proper terminology for such structures is needed in the light of fuller description and analysis.

\section{References}

American Geological Institute. 1957. Glossary of Geology and Related Sciences. Badgley, P. C. 1965. Structural and Tectonic Principles. New York.

Billings, M. P. 1972. Structural Geology (3rd ed.). New Jersey.

Challinor, J. 1967. A Dictionary of Geology (3rd ed.). Cardiff.

Conybeare, W. D. \& Phillips, W. 1822. Outlines of the Geology of England and Wales. London.

Dennis, J. G. 1967. International Tectonic Dictionary. Mem. Am. Ass. Petrol. Geol. 7. 
Gay, N.C. 1970. The formation of step structures on slickensided shear surfaces. J. Geol. 78, 523-32.

Hills, E. S. 1972. Elements of Structural Geology (2nd ed.). London.

Lindström, M. 1974. Steps facing against the slip direction: a model. Geol. Mag. 111, 71-4.

Lyell, C. 1874. The Student's Elements of Geology (2nd ed.). London.

Nevin, C. M. 1949. Principles of Structural Geology (4th ed.). New York.

Paterson, M. S. 1958. Experimental Deformation and Faulting in Wombeyan Marble. Bull. geol. Soc. Am. 69, 465-76.

Ramsay, J. G. (1967). Folding and Fracturing of Rocks. New York.

Read, H. H. \& Watson, J. 1962. Introduction to Geology. Volume 1. Principles. London.

Rod, E. 1966. A discussion of the paper: 'Fault plane features: an alternative explanation' by R. E. Riecker. J. sedim. Petrol. 36, 1163-5.

Schieferdecker, A. A. G. (Ed.) 1959. Geological Nomenclature. R. geol. Min. Soc. Neth.

Spencer, E. W. 1969. Introduction to the Structure of the Earth. New York.

Stočes, B. \& White, C. H. 1935. Structural Geology. London.

Tjia, H. D. 1964. Slickensides and fault movements. Bull. geol. Soc. Am. 75, 683-6.

Verhoogen, J., Turner, F. J., Weiss, L. E., Wahrhaftig, C. \& Fyfe, W. S. The Earth: an introduction to physical geology. New York.

Weaver, J. D. 1974. Jointing along the Swansea Valley Disturbance between Clydach and Hay-on-Wye, South Wales. Geol. Mag. 111, 329-36.

School of Geology

M. J. FLEUTY

Kingston Polytechnic

Kingston upon Thames

Surrey, U.K.

31 st August 1974

SIR - As Dr Fleuty has suggested, there is a great deal of ambiguity in the usage of the term slickenside and I am in agreement with him that a more narrowly defined set of terms would alleviate this confusion.

The slickensiding recorded previously (Weaver, 1974, pp. 332-3) may be defined as vertical, oblique or horizontal striations and grooves observed on polished surfaces, which is the informal meaning of the term used widely in the modern literature (Anderson, 1951, p. 17; Hancock, 1968, p. 144, 1969, p. 226, 1973, p. 516; Hills, 1972, p. 179; Holmes, 1965, p. 220; Moseley, 1968, p. 84, Phillips, 1964, p. 391; Ramsay, 1967, p. 394; Read \& Watson, 1962, p. 466).

I am not at all sure that the increase in terminology suggested by Dr Fleuty would be readily accepted or whether in fact it would not further complicate the interpretation of the term slickenside. However, if these new terms are acceptable may I suggest that the term slickenstriae may be preferable to slickenline for linear structures, seen on polished surfaces, resulting from friction.

\section{References additional to above}

Anderson, E. M. 1951. The Dynamics of Faulting (2nd ed.). Oliver \& Boyd.

Hancock, P. L. 1968. Joints and faults: the morphological aspects of their origins. Proc. Geol. Ass. 79, 141-51.

Hancock, P. L. 1969. Jointing in the Jurassic Limestones of the Cotswold Hills. Proc. Geol. Ass. 80, 219-41.

Hancock, P. L. 1973. Structural zones in Variscan Pembrokeshire. Proc. Ussher Soc. $2(6), 509-20$.

Holmes, A. 1965. Principles of Physical Geology. Nelson. 
Moseley, F. 1968. Joints and other structures in the Silurian rocks of the Southern Shap Fells, Westmorland. Geol. J. 6, 79-96.

Phillips, W. J. 1964. The structures in the Jurassic and Cretaceous rocks on the Dorset Coast between White Nothe and Mupe Bay. Proc. Geol. Ass. 75, 373-405.

Division of Geology

J. D. WEAVER

\author{
Derby College of Art and Technology \\ Kedleston Road \\ Derby DE3 1GB \\ 17th October 1974
}

\title{
Discussion of the function of extrathecal structures in graptoloids
}

SIR,-In their discussion of the function of the proximal structures developed in certain Llandovery graptoloids, Rickards \& Koren (Geol. Mag. 111 (3), 1974, pp. 193-204) seem to present two alternative interpretations involving mode of life. Since this is a subject with which I have been concerned for a number of years I would like to discuss the arguments leading to these interpretations.

In the flattened specimens of Orthograptus obuti figured and described by Rickards \& Koren, the proximal end of the rhabdosome lies between two layers of a black semicircular membrane. Rickards and Koren consider that the latter must have been secreted by extrathecal tissue, and conclude that 'the soft tissue was probably much more extensive than the skeletal hard parts'. The authors similarly regard the virgellar meshwork and long thecal spines of Orthograptus insectiformis as suggesting 'extensive amounts of extrathecal tissue surrounding the rhabdosome'.

They argue that 'the question of function then becomes one of querying the purpose of extensive quantities of extrathecal tissue' and that 'since Bulman (1957) has suggested that the extrathecal tissue may have been vacuolated tissue (i.e. containing quantities of gas as tiny bubbles), the membranous envelope in $O$. obut $i$ and the spinose bundle of Glyptograptus tabukensis could have held vacuolated extrathecal tissue which would, probably, have floated the rhabdosomes "upside-down"'.

However, they recognize that the planar element in the observed structures, the dorsoventral orientation of the membrane in $O$. obuti, and the extension of the spinose bundles in G. tabukensis in a plane at right angles to this, suggests that the function was 'one of stability in the currents; flotation may have been achieved in what is the more likely method in most graptolites, namely by concentration of vacuolated tissue along the nema or any developments thereof'. (In spite, presumably, of those quantities of vacuolated extrathecal tissue imagined within the membranous envelope of $O$. obuti and spinose bundle of $G$. tabukensis.)

In both of these conflicting interpretations, Rickards \& Koren seem to imply passive flotation of rhabdosomes buoyed up by vacuolated tissue 'probably much more extensive than the skeletal hard parts'. I have pointed out previously $(1969,1972 a)$ that a graptolite colony carried in passive suspension within an ocean current would have rapidly exhausted the food immediately surrounding it, and that the co-ordinated ciliary currents necessary to bring in sufficient food from further away would have resulted in reciprocal movement of the rhabdosome and the evolution of automobility. Ciliary currents causing upward movement during active feeding balanced by gravitational sinking when relatively inactive would have maintained the colony at the optimum overall level in the sea. Such diurnal movement seems to be almost universal among planktonic organisms, it would be strange indeed if it had not been shared by the graptoloids.

Geol. Mag. 112 (3), 1975, pp. 322-324. Printed in Great Britain 